\title{
Biological activity resulting from exposure to aquatic environmental genotoxic pollutants in northern Egypt
}

A.A. Saad, ${ }^{1}$ A.M. El-Sikaily, ${ }^{2}$ S.F. Kholeif, ${ }^{3}$ E.S. Khalil, ${ }^{4}$ H.S. Mahrous, ${ }^{3}$ E.M.S. Al-Zabedi ${ }^{5}$ and H.A. Kassem ${ }^{7}$

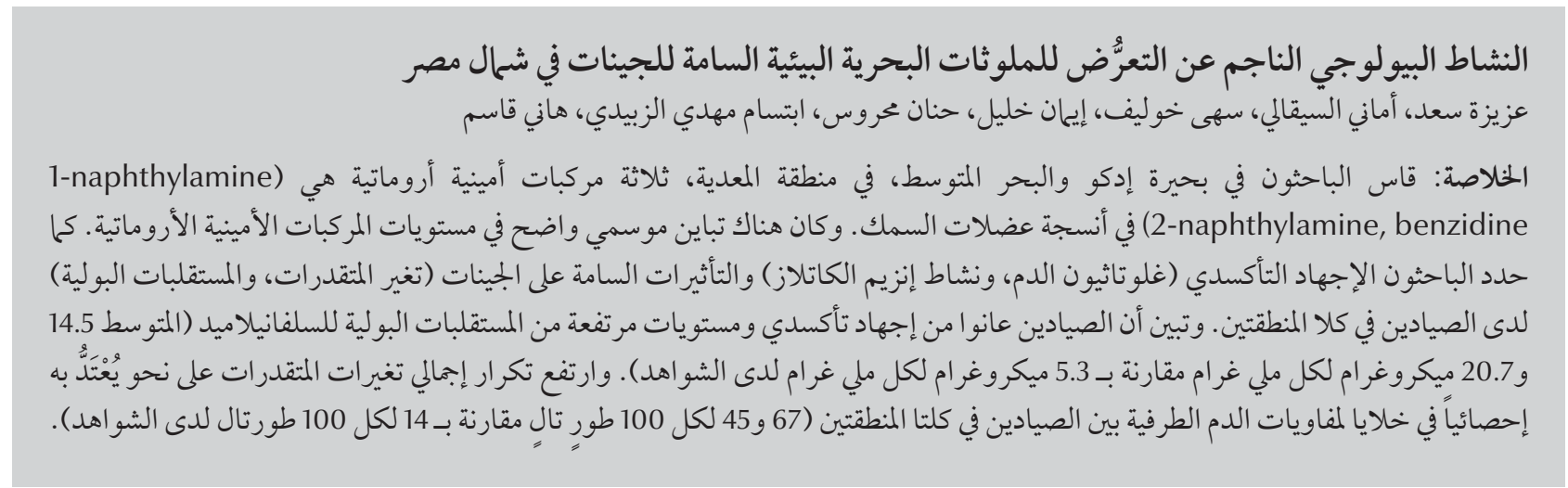

ABSTRACT We estimated pollution in Lake Edku and the Mediterranean Sea, El-Maadiya Region, with 3 aromatic amines (1-naphthylamine, 2-naphthylamine and benzidine) in the muscle tissue of fish. There were marked seasonal variations in the aromatic amine levels. We also determined oxidative stress (blood glutathione, and catalase activity) and genotoxic effects (chromosomal aberrations and urinary metabolites) in fishermen from each area. The fishermen suffered from oxidative stress and had high levels of the urinary metabolite sulfanilamide [mean ( $\mu \mathrm{g} / \mathrm{mg}$ creatinine): Lake Edku 20.7, Mediterranean 14.5, controls 5.3]. Frequencies for total chromosomal aberrations were significantly raised in the peripheral blood lymphocytes of fishermen in both areas [frequency (per 100 metaphases ): Mediterranean 67, Lake Edku 45, controls 14].

Activité biologique résultant de l'exposition à des polluants génotoxiques en milieu aquatique dans le nord de I'Égypte

RÉSUMÉ Nous avons réalisé une estimation de la pollution dans le lac Edkou et en Méditerranée (région d’ElMaadiya), sur la base de trois amines aromatiques (1-naphthylamine, 2-naphthylamine et benzidine) dans les tissus musculaires de poissons. Nous avons constaté de fortes variations saisonnières des niveaux d'amines aromatiques. Nous avons également déterminé le stress oxydatif (glutathion sanguin et activité de la catalase) et les effets génotoxiques (aberrations chromosomiques et métabolites urinaires) chez les pêcheurs de chaque région. Ces pêcheurs souffraient de stress oxydatif et présentaient des niveaux élevés de sulfanilamide, un métabolite urinaire [moyenne ( $\mu \mathrm{g} / \mathrm{mg}$ de créatinine) : lac Edkou 20,7, Méditerranée 14,5, témoins 5,3]. La fréquence des aberrations chromosomiques totales était significativement plus élevée dans les lymphocytes circulants des pêcheurs des deux régions [fréquence (pour 100 métaphases) : Méditerranée 67, lac Edkou 45, témoins 14].

${ }^{7}$ Department of Applied Medical Chemistry; ${ }^{3}$ Department of Human Genetics; ${ }^{4}$ Department of Internal Medicine, Medical Research Institute, Alexandria University, Alexandria, Egypt.

${ }^{2}$ Marine Pollution Laboratory, Environmental Division, National Institute of Oceanography and Fisheries, Alexandria, Egypt (Correspondence to A.M. El-Sikaily:dramany_mas@yahoo.com).

${ }^{5}$ Department of Applied Medical Chemistry. University of Sana'a, Sana'a, Yemen.

Received: 12/04/07; accepted: 02/09/07 


\section{Introduction}

The development of modern industry causes increasingly serious pollution in the environment where we live, constituting a catastrophic health risk, including for cancer [1]. Pollution of the aquatic environment is one of the worst legacies of development of the 20th century [1] and marine coastal areas are particularly impacted by human activities [2]. Aquatic ecosystems serve as a sink for pollutants, which bind to sediment and tend to accumulate in the tissues of aquatic organisms [3]. The concentrations of these compounds in the fresh tissues of aquatic organisms are several orders of magnitude higher than those found in the environment. Moreover, due to their lipophilic nature, organic compounds tend to bioaccumulate in fatty tissues [2].

Aromatic amines are environmental pollutants found in lakes, rivers and soil; they represent one of the most important classes of industrial and environmental chemicals. Many have been reported to be powerful carcinogens and/or haemotoxicants [4]. Their metabolites, $\mathrm{N}$-hydroxy arylamines and nitrosoarenes, react with $\mathrm{DNA}$, proteins and glutathione; the resulting damage to biomolecules is often responsible for the toxic or genotoxic effects [5].

In Egypt the coastal areas around El-Maadiya and LakeEdku are the main recipients for a number of pollutants from agriculture as well as industrial drainage.

The biomarker of exposure to these pollutants is the measurement of urinary metabolites. This enables the determination of the internal dose of pollutants and provides important information for biomonitoring of occupational and environmental human exposure [6].

Living beings are protected from reactive oxygen species (ROS) by several defence mechanisms, including glutathione, which has many antioxidant functions, such as control of the protein redox status and defence against free radicals and oxygen toxicity [7]. Most of these functions oxidize reduced glutathione (GSH) to the disulfide form (GSSG), the concentration of which is an index of oxidative stress [8]. Catalase is a haeme-containing enzyme which is localized in most mammalian cells exclusively in peroxisomes [9]. Human erythrocyteswith ahigh catalase content provide a general defence against toxic concentrations of hydrogen peroxide, while the lower the catalase activity in red cells, the more effective the action of the oxidizing agents [10]. Oxidative stress may result in damage to critical cellular macromolecules, including DNA, lipids, and proteins [11]. Oxidative DNA damage may participate in ROS-induced carcinogenesis [12]. A common form of damage is the formation of hydroxylated bases of DNA, which is considered an important event in chemical carcinogenesis [12]; this adduct formation interferes with normal cell growth by causing genetic mutations and altering normal gene transcription [12].

According to INCHEM guidelines, "Somatic mutations, either genetic or chromosomal, are not transmitted to the offspring of an exposed individual. However, increases in the frequency of these mutations may contribute to an increase in the frequency of acquired disorders, for example, cancer. There is, therefore, a clear need to develop and apply methods to study exposed populations at risk of increased levels of somatic or germinal mutations" [13].

Thus, the aim of this study was to estimate some aromatic amines in the flesh of fish taken from Lake Edku and the Mediterranean Sea at El-Maadiya and to investigate oxidative stress and chromosomal aberrations as biological markers reflecting the genotoxic effects of aquatic environmental pollutants in local fishermen.
The Mediterranean costal area of the north-eastern Egypt was selected for this study because it is the recipient of extensive agricultural and industrial wastes. The fresh water lake, Lake Edku, lies in the north of the Nile Delta, west of the Rosetta branch of the Nile between long $30^{\circ} 8^{\prime} 30^{\prime \prime} \mathrm{N}$ and $30^{\circ} 23^{\prime} 100^{\prime \prime} \mathrm{E}$ and is connected to the Mediterranean Sea through Boughaz El-Maadiya, a narrow, shallow channel. The hydrographic and biological characteristics of the water in El-Maadiya connection depend on the water exchange between Abu-Qir Bay and Lake Edku. Great amounts of industrial wastes are discharged into the bay through Tabia pumping station. These wastes come from about 36 factories in a cultivated area extending from Kafr El-Dawar to Alexandria. Tabia pumping station pumps the highly polluted water of ElAmia Drain, which receives the drainage from El-Behira district as well as the industrial wastes of the factories. These waste discharges originate from 5 main activities: the fertilizer industry, the pesticides industry, textile manufacturing, the paper industry and food processing and canning.

\section{Methods}

This study was carried out over the period 2002-2004. Males living in El Maadiya region were invited to take part in the study and about $60 \%$ of those we contacted agreed to participate. The study group comprised 102 male subjects with an average age of 38 (standard deviation 13) years; they were classified into 2 groups: non-fishermen, $(n=20)$ with low fish eating habits (healthy control group) and fishermen $(n=82)$. The fishermen were divided into 2 groups: Mediterranean Sea fishermen $(n=55)$ and Lake Edku fishermen $(n=27)$. 


\section{Determination of aromatic amines in fish flesh}

We followed the method of Diachenko [14] for the determination of selected industrial aromatic amines in fish. Samples of Tilapia sp. and Claris sp. were collected from Lake Edku, and samples of Mugil sp. and Siganus rivulatus from the Mediterranean Sea in El-Maadiya region during the 4 seasons (winter, spring, summer and autumn). The flesh of the fish was separated and the skin removed. The fish flesh was dried in an incubator at $37-40^{\circ} \mathrm{C}$ for $2-7$ days depending on the size of the fish. After drying, a mechanical grinder was used to grind the fish to powder form.

The fish powder was digested with aqueous $\mathrm{NaOH}$ and extracted with benzene. The extract was washed with diluted acid and cleaned up using silica gel column chromatography. The amines were separated, and quantitatively determined by gas chromatography-mass spectrometry using a fully automated mass spectrometer (Agilent model HP6890) equipped with HPdata system to acquire and process all GC-MS data. A gas chromatograph (Agilent) was interfaced to the mass spectrometer and fitted with a capillary column (model HP19091S-433) with HP-5 on 5\% phenyl methyl siloxane, with nominal length $30 \mathrm{~m}$, nominal diameter $250 \mu \mathrm{m}$ and nominal film thickness $0.25 \mu \mathrm{m}$.

\section{Blood analyses}

The participants were requested to fast for 6 hours. Samples of peripheral blood $(10 \mathrm{~mL})$ were collected by a physician by venepuncture in heparinized tubes at the Medical Research Institute in Alexandria. The blood samples were processed immediately.

Blood glutathione content was determined using $0.2 \mathrm{~mL}$ of whole blood according to the method of Beutler E, Duron O, Kelly BM [15]. DTNB reagent was obtained from Sigma Chemical Company and optical density was measured at $412 \mathrm{~nm}$ using a PRIME automatic photometer (BPC BioSED srl, Italy).

Erythrocyte catalase activity was determined according to the method of Donald and Hugo [16]. The concentrated haemolysate was diluted 500 times $(\mathrm{v} / \mathrm{v})$ with phosphate buffer immediately before carrying out the assay (in duplicate) to determine haemoglobin content using the method of Drabkin [17]. The enzyme activity level was measured at $412 \mathrm{~nm}$.

\section{Determination of urinary sulfanilamide}

Early morning urine samples were collected from those participants who had abnormal levels of blood glutathione $(<35 \mathrm{mg} / \mathrm{dL})$ and/or erythrocyte catalase activity $(<805 \mathrm{U} / \mathrm{g} \mathrm{Hb})$ to detect urinary metabolites of aromatic amines (sulfanilamides) according to the method of Hayashi M, Amino G, Uchida MS [18].

\section{Cytogenetic analysis}

Blood culture for chromosome aberrations was carried out according to the methods described by Smerhovsky Z et al. [19]. One hundred metaphases were counted and scored for structural chromosomal aberrations according to the International System for Human Cytogenetic Nomenclature (ISCN).

\section{Statistical analysis}

The data obtained were statistically analysed using SPSS, version 10. One way analysis of variance was used to compare between the levels of the different parameters in the study groups. A difference was considered significant at $P<0.05$.

\section{Results}

\section{Oceanographic data}

The pollution status of Lake Edku and the Mediterranean Sea (El-Maadiya region) was studied by estimating the levels of 1-naphthylamine, 2-naphthylamine and benzidine in the muscle tissue of 4 types of fish: Tilapia sp. and Claris sp. from Lake Edku and Mugil sp. and Siganus rivulatus from the Mediterranean Sea.

High concentration of 1-naphthylamine and benzidine were found in Tilapia sp. in summer (Table 1) while high concentrations of 2-naphthylamine were found in spring. In Claris sp. the concentration of 1-naphthylamine was high in all seasons except spring, and high concentrations of 2-naphthylamine and benzidine were found in spring and summer (Lake Edku).

Elevated levels of all 3 aromatic amines were found in autumn in Mugil sp., the 3 aromatic amines were found in elevated levels in Siganus revulatus in all 4 seasons (Mediterranean Sea).

\section{Biochemical data}

Statistical analysis between groups (1-way ANOVA) showed a significantly lower blood glutathione level in both groups of fishermen compared with the control group $(P<0.001)$ (Table 2). Erythrocyte catalase activity was significantly lower in both the fishermen groups compared with the control group $(P<0.001)$ (Table 2$)$. Significantly higher urinary sulfanilamide levels were seen in both fishermen groups compared with the control group $(P<0.001)$ (Table 2$)$.

There was a significant negative correlation between urinary sulfanilamide $(\mu \mathrm{g} / \mathrm{mg}$ creatinine) and blood glutathione $(\mathrm{mg} / \mathrm{dL})$ content in the studied groups $(r=-0.549, P=0.004)$ (Figure 1 , available in online version). There was also a significant negative correlation between urinary sulfanilamide $(\mu \mathrm{g} / \mathrm{mg}$ creatinine) and erythrocyte catalase enzymatic activity $(\mathrm{U} / \mathrm{g} \mathrm{Hb})(r$ $=-0.523, P=0.006$ ) (Figure2, available in online version). 


\begin{tabular}{|c|c|c|c|}
\hline Species \& season & $\begin{array}{l}\text { 1-Naphthylamine } \\
\text { ( } \mu \mathrm{g} / \mathrm{kg} \text { dry weight) }\end{array}$ & $\begin{array}{l}\text { 2-Naphthylamine } \\
\text { ( } \mu \mathrm{g} / \mathrm{kg} \text { dry weight) }\end{array}$ & $\begin{array}{c}\text { Benzidine } \\
\text { ( } \mu \mathrm{g} / \mathrm{kg} \text { dry weight) }\end{array}$ \\
\hline \multicolumn{4}{|l|}{ Tilapia sp. ${ }^{a}$} \\
\hline Winter & - & - & - \\
\hline Spring & - & 932 & - \\
\hline Summer & 2801 & - & 934 \\
\hline Autumn & - & - & - \\
\hline \multicolumn{4}{|l|}{ Claris sp. ${ }^{a}$} \\
\hline Winter & 1060 & - & - \\
\hline Spring & - & 3476 & 2812 \\
\hline Summer & 4019 & 3221 & 952 \\
\hline Autumn & 3480 & - & - \\
\hline \multicolumn{4}{|l|}{ Mugil sp. ${ }^{\mathrm{b}}$} \\
\hline Winter & - & - & - \\
\hline Spring & - & - & - \\
\hline Summer & - & - & - \\
\hline Autumn & 1713 & 1286 & 650 \\
\hline \multicolumn{4}{|l|}{ Siganus revulatus ${ }^{\text {b }}$} \\
\hline Winter & 3213 & 2048 & 1347 \\
\hline Spring & 3765 & 953 & 618 \\
\hline Summer & 2742 & 2989 & 1185 \\
\hline Autumn & 5541 & 2148 & 975 \\
\hline
\end{tabular}

${ }^{a}$ From Lake Edku. ${ }^{b}$ From the Mediterranean Sea, El-Maadiya region.

\begin{tabular}{|c|c|c|c|}
\hline \multicolumn{4}{|c|}{$\begin{array}{l}\text { Table } 2 \text { Oxidative stress markers in the blood of a healthy control group and } 2 \\
\text { groups of fishermen from El-Maadiya region }\end{array}$} \\
\hline Oxidative stress marker & $\begin{array}{l}\text { Controls } \\
(n=20)\end{array}$ & $\begin{array}{l}\text { Mediterranean } \\
\text { Sea fishermen } \\
\quad(n=55)\end{array}$ & $\begin{array}{l}\text { Lake Edku } \\
\text { fishermen } \\
\quad(n=27)\end{array}$ \\
\hline \multicolumn{4}{|l|}{$\begin{array}{l}\text { Glutathione (mg/dL whole } \\
\text { blood) }\end{array}$} \\
\hline Mean & 39.95 & 34.36 & 34.41 \\
\hline SD & 2.96 & 5.63 & 6.16 \\
\hline SE & 0.66 & 0.76 & 1.19 \\
\hline Range $^{a}$ & $35-44$ & $25-46$ & $19-45$ \\
\hline \multicolumn{4}{|l|}{$\begin{array}{l}\text { Erythrocyte catalase activity } \\
(\mathrm{U} / \mathrm{g} \mathrm{Hb})\end{array}$} \\
\hline Mean & 974.00 & 661.00 & 589.30 \\
\hline SD & 92.20 & 146.90 & 117.12 \\
\hline SE & 20.62 & 19.81 & 22.54 \\
\hline Range $^{b}$ & $1163-805$ & $933-352$ & $858-329$ \\
\hline $\begin{array}{l}\text { Urinary sulfanilamide }(\mu \mathrm{g} / \mathrm{mg} \\
\text { creatinine) }\end{array}$ & $(n=9)$ & $(n=13)$ & $(n=6)$ \\
\hline Mean & 5.3 & 14.5 & 20.7 \\
\hline SD & 3.1 & 9.4 & 9.65 \\
\hline SE & 1.0 & 2.5 & 3.9 \\
\hline Range $^{c}$ & $0.5-9.9$ & $4.1-35.1$ & $6.1-33.1$ \\
\hline
\end{tabular}

${ }^{a} F=8.634, P<0.001 ;{ }^{b} F=56.294, P<0.001 ;{ }^{c} F=4.278, P=0.024$ (1-way analysis of variance). $S D=$ standard deviation; $S E=$ standard error; $H b=$ haemoglobin.

\section{Cytogenetic results}

Table 3 compares the frequencies of different types of chromosomal aberrations in each group. Chromosome-type exchanges, chromosome-type breaks plus exchanges, chromosome-type aberrations, total breaks plus exchanges as well as total chromosomal aberrations were significantly increased in both fishermen's groups compared with the control group $(P=0.003, P$ $=0.001, P<0.001, P=0.001, P=0.001$ respectively). There was a highly significant negative correlation between total chromosomal aberrations "excluding gaps" (/100 metaphases) and blood glutathione content in the studied groups $(r=-0.648, P<0.001)$ (Figure 3 , available in online version). There was also a significant negative correlation between total chromosomal aberrations excluding gaps and erythrocyte catalase enzymatic activity $(r=-0.672$, $P<0.001$ ) (Figure 4, available in online version). Finally, there was a significant positive correlation between total chromosomal aberrations excluding gaps and urinary sulfanilamide in the 3 groups $(r=0.488, P=0.011)$ (Figure 5, available in online version).

\section{Discussion}

Concentrations of the 3 studied aromatic amines were highly elevated in Claris sp. compared with Tilapia sp. Additionally, Tilapia sp. was free from all 3 aromatic amines in winter and autumn, while Claris sp. was free from 2-naphthylamine and benzidine in winter and autumn. The variation may be related to the feeding habits or the greater body size and body fat content of Claris sp. [20].

In addition, a marked elevation in concentrations of the 3 studied aromatic amines was detected in Siganus revulatus, while in Mugil sp., the pollution occurred only in autumn. This may be due to the feeding habits and species 
differences. These finding are in agreement with the results of other studies which found that the mean concentration of pollutants in the sea animals varied according to species, season and area $[21,22]$. High levels of genotoxic elements in fish can confirm the pollution of sea water and the possibility of the presence of genotoxic elements [23].

The biochemical results of this study shows that the fishermen groups of Lake Edku and El-Maadiya region of the Mediterranean Sea were suffering from oxidative stress, which manifested in a significant decrease in the levels of both whole blood glutathione and erythrocyte catalase enzymatic activity compared with the control group. A significantly high level of the urinary metabolite sulfanilamide was found in both fishermen groups in comparison with the control group. Sulfanilamide stimulates the formation of methaemoglobin in red blood cells; this may be a result of exposure to pollutants such as aromatic amines and pesticides during recreational activities as well as high consumption of polluted fish [24].

Oxidative stress may result in damage to critical cellular macromolecules, including DNA, lipids, and proteins [11]. Oxidative DNA damage may participate in ROS-induced carcinogenesis [12]. A common form of damage is the formation of hydroxylated DNA bases, which are considered an important event in chemical carcinogenesis $[12,25]$. This adduct formation interferes with normal cell growth by causing genetic mutations and altering normal gene transcription.

To counteract oxidative stress, the human body has evolved various defence mechanisms [26]. Antioxidants, which scavenge the reactive oxygen species prior to their interaction with cellular components are the first line of defence against exogenous oxidative stress [26]. If a large amount of the toxic substance is present then the detoxication mechanisms are overwhelmed. Excess superoxide is produced, reduced glutathione and NADPH are depleted and hydroxyl radicals and singlet oxygen are formed [27].

Chromosomal analysis of peripheral human lymphocytes is the most widely used method for biomonitoring human exposure to genotoxic chemicals. In our study, the frequency of chromosomal aberrations in fishermen exposed to benzidine was significantly higher than in the control group. Data on the chromosomal effect of human exposure to benzidine is, however, scarce. Mirkova and Lalchev observed a statistically significant increase in frequency of chromosome aberrations in lymphocytes of workers exposed to benzidine compared to a control group [28], an observation in accordance with our own findings. In contrast to our study, the main type of aberration observed in the Mirkova and Lalchev study [28] was chromatid breaks, whereas the main type of aberrations we observed was chromosome exchanges. The presence of dicentric, rings and chromatid exchanges in our study confirms the very high dose of benzidine to which these fishermen have been exposed, and demonstrates the mutagenic effect of benzidine on the lymphocytes.

The chromosomal aberration assay has also been shown to be a convenient test for somatic risk assessment. Clear evidence has been presented that an enhanced frequency of chromosomal aberrations correlates with an increased incidence of cancer in epidemiological

\begin{tabular}{|c|c|c|c|c|c|c|c|c|}
\hline \multirow[t]{2}{*}{ Chromosomal aberration } & \multicolumn{2}{|r|}{$\begin{array}{c}\text { Controls } \\
(n=6)\end{array}$} & \multicolumn{2}{|c|}{$\begin{array}{l}\text { Mediterranean Sea } \\
\text { fishermen }(n=13)\end{array}$} & \multicolumn{2}{|c|}{$\begin{array}{l}\text { Lake Edku fishermen } \\
\qquad(n=7)\end{array}$} & \multicolumn{2}{|c|}{ ANOVA } \\
\hline & Freq $^{a}$ & Mean (SD) & Freq $^{\mathrm{a}}$ & Mean (SD) & Freq $^{a}$ & Mean (SD) & $\boldsymbol{F}$ & $P$ \\
\hline Chromosome-type gap & 0 & 0 & 2 & $0.002(0.004)$ & 3 & $0.004(0.005)$ & 2.13 & 0.141 \\
\hline Chromosome-type break & 0 & 0 & 6 & $0.005(0.008)$ & 6 & $0.010(0.011)$ & 1.94 & 0.167 \\
\hline Chromosome-type exchange & 4 & $0.007(0.008)$ & 39 & $0.030(0.014)$ & 27 & $0.040(0.020)$ & 7.79 & 0.003 \\
\hline $\begin{array}{l}\text { Chromosome-type break + } \\
\text { exchange }\end{array}$ & 4 & $0.007(0.008)$ & 45 & $0.035(0.016)$ & 33 & $0.047(0.023)$ & 9.95 & 0.001 \\
\hline Chromosome-type aberration & 4 & $0.007(0.008)$ & 47 & $0.036(0.016)$ & 38 & $0.051(0.022)$ & 12.11 & $<0.001$ \\
\hline Chromatid-type gap & 10 & $0.017(0.010)$ & 19 & $0.015(0.011)$ & 7 & $0.010(0.010)$ & 0.69 & 0.512 \\
\hline Chromatid-type break & 0 & 0 & 0 & 0 & 0 & 0 & - & - \\
\hline Chromatid-type exchange & 0 & 0 & 1 & $0.001(0.003)$ & 0 & 0 & 0.48 & 0.625 \\
\hline Chromatid-type break + exchange & 0 & 0 & 1 & $0.001(0.003)$ & 0 & 0 & 0.48 & 0.625 \\
\hline Chromatid-type aberration & 10 & $0.020(0.010)$ & 20 & $0.015(0.012)$ & 7 & $0.010(0.010)$ & 0.72 & 0.499 \\
\hline Total breaks + exchanges & 4 & $0.007(0.008)$ & 46 & $0.035(0.015)$ & 33 & $0.047(0.023)$ & 10.74 & 0.001 \\
\hline Total aberrations & 14 & $0.023(0.005)$ & 67 & $0.052(0.020)$ & 45 & $0.061(0.002)$ & 8.86 & 0.001 \\
\hline
\end{tabular}

${ }^{a}$ Freq $=$ frequency of chromosomal aberrations $/ 100$ metaphases

ANOVA = analysis of variance; $S D=$ standard deviation. 
surveys and is of predictive value for subsequent cancer risk [29-32]. We found an elevated level of the herbicide metabolite sulfanilamide in the urine of both groups of fishermen. There was a negative correlation between sulfanilamide and both glutathione and catalase activity.

Our study also demonstrated a high frequency of chromosomal aberrations in the peripheral blood lymphocytes of both fishermen groups. There was a positive correlation between sulfanilamide and chromosomal aberrations, and a negative correlation between chromosomal aberrations and both glutathione and catalase activity were found. Therefore, it may be considered that oxidative stress and sulfanilamide contribute to the induction of chromosomal aberrations, and a consequential serious effect on human health.

\section{Conclusion}

Our findings emphasize that the pollution of El-Maadiya region induces a panic oxidative stress in fishermen in the vicinity of this area. The risk will persist because of the decrease in the levels of antioxidant glutathione and catalase enzyme activity in the blood of fishermen.

These findings indicate that oxidative biomarkers in combination with other types of biomarkers (chromosomal aberrations) can be useful in the large scale for environmental monitoring.

\section{References}

1. Hiramoto K, Ohkawa T, Kikugawa K. Release of nitric oxide together with carbon-centered radicals from $\mathrm{N}$-nitrosamines by ultraviolet light irradiation. Free radical research, 2001, 35:803-13.

2. Varanasi U. Metabolism of polycyclic aromatic hydrocarbons in the aquatic environment. Boca Raton, Florida, CRC Press, 1989:341.

3. Corsi I et al. Monitoring a marine coastal area: use of Mytilus galloprovincialis and Mullus barbatus as bioindicators. Marine ecology, 2002, 23(1):138-53.

4. Benigni R, Passerini L. Carcinogenicity of the aromatic amines: From structure- activity relationships to mechanisms of action and risk assessment. Mutation research, 2002, 511:191-206.

5. Zwirner-Baier I, Neumann HG. Biomonitoring of aromatic amines $\mathrm{V}$ : acetylation and deacetylation in the metabolic activation of aromatic amines as determined by haemoglobin binding. Archives of toxicology, 1998, 72(8):499-504.

6. Falck K. Biological monitoring of occupational exposure to mutagenic chemicals in the rubber industry. Use of the bacterial urinary mutagenicity assay. Scandinavian journal of work, environment \& health, 1983, 9(Suppl. 2):39-42.

7. Kosower NS, Kosower EM. The glutathione status of cells. International review of cytology, 1978, 54:109-60.

8. Alonso-Moraga $\mathrm{A}$ et al. Glutathione status and sensitivity to GSH-reacting compounds of Escherichia coli strains deficient in glutathione metabolism and/or catalase activity. Molecular \& cellular biochemistry, 1987, 73:61-8.

9. Albrecht W. Enzymes acting against reactive oxygen. In: Goldberg DM, Moss DW, Schmidt E, eds. Enzymes: tools and targets. Proceedings of the 6th International Congress on Clinical Enzymology, Hannover. Advances in clinical enzymology, 1988, 6:161-7.

10. Mueller S, Riedel HD, Stremmel W. Direct evidence for catalase as the predominant $\mathrm{H} 2 \mathrm{O} 2$-removing enzyme in human erythrocytes. Blood, 1997, 90:4973-8.

11. Klaunig JE et al. The role of oxidative stress in chemical carcinogenesis. Environ health perspectives, 1998, 106:289-95.

12. Breimer LH. Molecular mechanisms of oxygen radical carcinogenesis and mutagenesis: the role of DNA base damage. Molecular carcinogenesis, 1990, 3:188-97.

13. INCHEM, International Programme on Chemical Safety. Guidelines for the study of genetic effects in human populations. Geneva, World Health Organization, United Nations Environment
Programme, International Labour Organisation, 1985 (Environmental Health Criteria 46) (http://www.inchem.org/documents/ehc/ehc/ehc46.htm, accessed 10 November 2009).

14. Diachenko GW. Determination of several industrial aromatic amines in fish. Environmental science and technology, 1979, 13:329-33.

15. Beutler E, Duron O, Kelly BM. Improved method for the determination of blood glutathione. Journal of laboratory \& clinical medicine, 1963, 61:882-8.

16. Donald W, Hugo E. Enzymes I: Oxidoreductases, transferases. In: Bergmeyer HU, Bergmeyer J, Grassi M, eds. Methods of enzymatic analysis, 3rd ed. Weinheim/Basel, Verlag Chemie, 1987:273-86.

17. Drabkin DL. Crystallographic and optical properties of the hemoglobin of man in comparison with those of other species. Journal of biological chemistry, 1946; 164:703-23.

18. Hayashi M, Amino G, Uchida MS. High performance liquid chromatographic determination of primary aromatic amines in urine after derivatization to an azo dye with 2-aminoanthracine. Journal of chromatography, 1995, 665:209-12.

19. Smerhovsky $Z$ et al. Risk of cancer in an occupationally exposed cohort with increased level of chromosomal aberrations. Environmental health perspectives, 2001, 109:41-5.

20. Neely WB. Chemicals in the environment. New York, Marcel Dekker, 1980:15-7.

21. Saad AA et al. Effect of polluted fish intake on Interleukin 1, 2 production, phagocytic function of mononuclear phagocytes and liver $\beta$-glucuronidase in rats. Journal of the Medical Research Institute, 1998, 19:126-41.

22. Papadopoulou C, Kanias GD. Trace element distribution in seven mollusc species from Saronikos Gulf. Acta adriatica, 1976, 18:367-78.

23. Uysal H. Accumulation and distribution of heavy metals in some marine organisms in the bay of Izmir and in Aegean coasts (Turkey). IV. Journées études pollutions, Antalya, CIESM, 1978, 4:213-7.

24. Zenser TV et al. Methemoglobin oxidation of N-acetylbenzidine to form a sulfinamide. Drug metabolism and disposition, 2001, 29:401-6.

25. Chaudhary AK et al. Analysis of the malondialdehyde-2'-deoxyguanosine adduct in rat liver DNA by gas chromatograph/ electron capture negative chemical ionization mass spectrometry. Biological mass spectrometry, 1994, 23:457-64. 
26. Besaratinia A et al. A multi-biomarker approach to study the effects of smoking on oxidative DNA damage and repair and antioxidative defense mechanisms. Carcinogenesis, 2001, 21:395-401.

27. Timbrell J, ed. Principles of biochemical toxicology. London, Taylor \& Francis, 2000:199-200.

28. Mirkova ET, Lalchev SG. The genetic toxicity of the human carcinogens benzidine and benzidine-based dyes: chromosomal analysis in exposed workers. Mutation and the environment 1990, 3:397-405.

29. Hagmar L et al. Cancer risk in human predicted by increased levels of chromosomal aberrations in lymphocytes: Nordic study group on the health risk of chromosome damage. Cancer research, 1994, 54:2919-22.

30. Toyokumi S. Reactive oxygen species-induced molecular damage and its application in pathgology. Pathology international, 1999, 49:91-102.

31. Amici $M$ et al. Peroxynitrite-induced oxidation and its effects on isolated proteasomal systems. Free radical biology \& medicine, 2003, 34:987-96.

32. Huttner E, Gotze A, Ni Kolova T. Chromosomal aberration in humans as genetic endpoints to assess the impact of pollution. Mutation research, 1999, 445:251-7.

\section{Principles for modelling dose-response for the risk assessment of chemicals}

This volume, Principles for modelling dose-response for the risk assessment of chemicals, is part of the ongoing review of the underlying scientific bases for decision-making in chemical risk assessment by International Programme on Chemical Safety. It involves specific consideration of the area of dose-response assessment in the evaluation of information from toxicological studies in animals and from human clinical and epidemiological studies. It covers toxicants with threshold effects and those for which there may be no practical threshold, such as substances that are genotoxic and carcinogenic. The discussions are concerned with that subset of cause-effect relationships commonly referred to as dose-response models, which are typically used to characterize the biological effects of intentional (e.g. drugs and nutrients) and unintentional (e.g. contaminants) exposure to chemicals.

This report is intended primarily to provide descriptive guidance for risk assessors in using dose-response modelling in hazard characterization. It will also provide mathematical modellers with an appreciation of issues to be considered when modelling in the context of the risk assessment process. Risk managers will be able to obtain a general understanding of the applications and limitations of dose-response modelling. For both risk assessors and risk managers, some considerations for communicating the results of risk assessments that use dose-response modelling are presented

Further information about this and other WHO publications can be found at: http://www.who.int/bookorders/ anglais/home1.jsp?sesslan=1 